\title{
EDA2R wt Allele
}

National Cancer Institute

\section{Source}

National Cancer Institute. EDA2R wt Allele. NCI Thesaurus. Code C159365.

Human EDA2R wild-type allele is located in the vicinity of Xq12 and is approximately $45 \mathrm{~kb}$ in length. This allele, which encodes tumor necrosis factor receptor superfamily member 27 protein, is involved in signaling that modulates the development of ectodermal structures. 